\title{
EFFECT OF THREE STOCKING DENSITIES AND THREE DIETS ON GROWTH AND SURVIVAL OF POST LARVAL MACROBRACHUIM VOLLENHOVENII(HERLOT'S 1857) DECAPODA; PALAEMONIDAE)
}

PAUL J. UDO

(Received 24 May 2001, Revision Accepted 4 Aug. 2003)

\section{ABSTRACT}

Growth and survival rate of Macrobrachium vollenhovenii (Herklots) post larvae reared in aquaria were monitored for 98 days at 3 stock densities and for 84 days in the specimens fed with three different compounded meals. Specimens at the stock density of 16 ind $\mathrm{m}^{2} \cdot 27$ ind $\mathrm{m}^{2}$ and 54 ind. $\mathrm{m}^{2}$ showed specific growth rates of $0.52 \%, 0.96 \%$ and $0.64 \%$ obtaining a daily weight gain of $0.008 \mathrm{~g} \mathrm{~d}^{-1}, 0.009 \mathrm{gd}^{-1}$ and $0.005 \mathrm{~g} \mathrm{~d}^{-1}$ respectively. Growth obtained from animals that fed on meal $\mathrm{CM}_{3}(48.5 \%$ crude protein content) was better compared to the growth rates of $0.02 \mathrm{~g}^{-1} \mathrm{~d}^{-1}$ determine in specimen that relied on meal $\mathrm{CM}_{1}\left(55 \%\right.$ crude protein content) and $\mathrm{CM}_{2}$ ( $30.6 \%$ crude protein content) respectively. Survival rates of $50 \%$ were determined in all levels of the feed experiment while $100 \%$ survival was calculated in all stock densities except in the 54 -irid. $\mathrm{m}^{2}$ density, which gave $40 \%$ survival. These results are exhaustively discussed in relation to the culture of Macrobrachium vollenhovenii

KEY WORDS: Stocking densities, Meal, growth, Survival, and Macrobrachium vollenhovenii.

\section{INTRODUCTION}

Growth studies in aquatic organisms are usually investigated in relation to both environmental and inherent factors such as temperature, sexual dimorphism, predation, food and survival. which influences growth in several ways (Sarver, et al, 1982; Malecha , 1986). Sarver et al (1982) emphasized that environmental factors are site specific such that growth data from species reared in different environments should be compared with caution.

Several authorities have studied growth in many species of crustaceans including Macrobrachium rosenbergii (Sandifer and Smith 1975; Willis et al 1976; Willis and Berrigam,1977), $M$. acanthurus and $M$. carcinus (Dobkin et al 1974) and Austropomabius pallipes (Pratten 1980) etc. Studies on the growth of crusteceans in relation to several kinds of compounded feeds produced from different raw materials are also reported in literature (Viola et al,1988; Manik et al 1977; Destajo and Dejarme,1982; D'Abramo et al 1981; Davis and Robinson.1986). Gutherie and Tarver(1981) reported that the mean final size of specimens under culture was lower at higher densities and when they were fed with unacceptable supplemental diets. Survival rates of specimens also depend on stock densities and the length of the growth period (Sandifer and Smith, 1975; Prah, 1982; Gordon, 1978; Udo and Tacge, 1989):

In this study, the author provides for the first time data on the growth of Macrobrachium vollenhovenii stocked at different densities and on individuals fed with compounded feeds produced from local sources of raw ingredients. $M$. vollenhovenii is the largest fresh water shrimp in West Africa (Prah,1987; Udo and Taege,1991) and its potential for culture is being investigated in Calabar, Nigeria and Hamburg, Germany. The species is locally preferred as delicacy and a shrimp species of great economic importance to artisanal fisheries. It is presently over fished (Enin,1994) and may become unavailable or extinct in the future. Its biology and culture potentials must be discovered now for its subsequent cultivation. Powell(1982) recorded a maximum length of $180 \mathrm{~mm}$ for the species but the largest available individual now is about $130 \mathrm{~mm}$ long (Enin, 1994).

\section{MATERIALS AND METHODS}

All post larvae were caught from the $\mathrm{Kwa}$ falls which is located between latitude $5^{\circ} 12^{1}$ and $5^{\circ} 40^{1} \mathrm{~N}$ and longitudes $10^{\circ} 2$ and $10^{\circ} 15^{1} \mathrm{~S}$ in the rain forest belt of Nigeria and about $36 \mathrm{~km}$ from Calabar, Nigeria. In the laboratory, they were acclimatized before commencement of study. The water for the study was collected at the Kwa falls while subsequent water used for exchange and replacement were aged and stabilised tap water which had the initial $\mathrm{pH}$ of 4.3 and later (stabilized by addition of known quantities of sodium bicarbonate to a properly aerated tap water) 7.5 after stabilization

\section{Growth at three stocking densities}

Three pairs of aquaria each measuring $0.27 \mathrm{~m}^{2}$ were used for the stocking of the specimens after the initial mean weights and total lengths of the arimals were measured. Each of the aquaria with replicates was stocked at the density of 16 ind. $m^{2} ; 27$ ind $m^{2}$ and 54 ind $\mathrm{m}^{2}$ respectively. In a addition to a sandy substratum, which was later replaced with muddy bottom, each aquaria was provided with adequate 'shelters '(hideouts). The change in substratum (and the shelters) from sand to mud is related to the change in behaviour of specimens from pelagic to benthos habit as they mature (New and Singholka,1982). These specimen were fed with Egaria radiata and fish flesh meals at the 
Table 1: $\quad$ Percentage and proximate composition of nutrients in the compounded meals for Macrobrachium vollenhovenii post larvae.

\begin{tabular}{lccc}
\hline \multicolumn{1}{r}{ Food ingredients } & \multicolumn{2}{c}{ Compounded meals code components (\%) } \\
\cline { 3 - 4 } & $\mathrm{CM}_{1}$ & $\mathrm{CM}_{2}$ & $\mathrm{CM}_{3}$ \\
\hline Groundnut & 43.2 & - & 27.3 \\
Shrimp meal & 34.8 & - & 27.3 \\
Egaria radiata meal & 7 & 45.4 & 13.6 \\
Plankton & 4.3 & 4.5 & 4.5 \\
Water lily & - & 2.3 & 9.1 \\
Palm oil & - & 4.5 & - \\
Binder(garri starch) & 4.3 & 4.5 & 4.5 \\
Vitamin premix & 13.0 & 13.6 & 13.6 \\
$\quad$ Total & 99.9 & 99.8 & 99.9 \\
Proximate composition & & & \\
Crude protein(\%) & 55 & 30.5 & 48.5 \\
Ash(\%) & 18.3 & 14.9 & 16.4 \\
Crude fat(\%) & 6.6 & 6.1 & 7.2 \\
Nitrogen Free extract(NFE) & 23.0 & 34.3 & 21.4 \\
Others(\%) & 17.1 & 14.1 & 6.5 \\
& 100 & 100 & 100 \\
\hline
\end{tabular}

feeding rate of $20 \%$ body weight divided into three rations per day. Fish in every aquaria were fed with the same meal on the same day to exclude the influence of food type on growth. This feeding rates was adjusted every 14 days until the end of the study on the $98^{(t)}$ day when the total lengths and weights of the animals were re-measured.

Cleaning and partial replacement of water in the culture systems were carried out every two days, while complete water replacement was undertaken every 14 days. Uneaten food and other wastes were siphoned daily before next feeding to ensure the maintenance of good water quality of the culture media.

\section{Growth with compounded food}

Three types of artificiaily compounded food were investigated; their constituents and proximate composition are given in table 1. Proximate analysis were done according to standard procedures; crude protein determined by the Macro kjeldal method; fat by soxhlet extraction; moisture by drying; ash by furnace ashing and Nitrogen free extract by difference(AOAC, 1975).

Six aquaria each measuring $0.27 \mathrm{~m}^{2}$ with replicates were used for this aspect of the study. The animals were stocked at equal densities of 33 ind. $\mathrm{m}^{2}$ after the initial mean weights and total lengths were determined. Feeding was carried out thrice daily at an initial rate of $20 \%$ mean body weight of animals shared to provide three rations in a day. The feeding rates were adjusted in steps of $1 \%$ every 14 days of culture to match with the new weights of the animals (New and Singholka, 1982). The method of cleaning of aquaria and water exchange was as earlier described. Water qualities of dissolved oxygen and $\mathrm{pH}$ were monitored and regulated daily to suit the water quality of it natural habitat. The final total lengths and weights of the animals were taken including the weights of food consumed. The growth rates(including specific growth
I, food conversion rates (FCR) and production efficiencies (PE)were computed according to the method used by Sandifer and Smith,(1970)

To determine the differences in growths of the treatment groups data were compared by use of oncway analysis of variance(ANOVA) and the least significance range test (Sokal and Rohlf, 1970).

\section{RESULTS}

Body weights of specimen increased with time irrespective of stock density and food: Animals also modified habitat changing from pelagic to benthos habit when bottom substrate of the culture systems was changed from sand to mud. Water quality was maintained as follows: Dissolved oxygen $=6.85$ and $\mathrm{pH}$ was between 6.75 and 7.00 .

\section{Effect of stocking density on growth.}

Growth was similar in stock densities 16 and 27 ind $\mathrm{m}^{2}$ (Table II) and was different in

54 ind. $m^{2}\left(F_{s}=8.86 ; 3\right.$ and $\left.28 d f\right)(P>0.05)$. Further test for variability confirmed that specimens stocked at 54ind. $\mathrm{m}^{2}$ density were more variable than the others. Tables 11 and III also show that survival and growth rates at stock densities 16 and 27 ind $\mathrm{m}^{2}$ were similar $(P>0.05)$ while the lowest survival rates of $40 \%$ were calculated from the tanks with highest stock density of individuals.

\section{Effect of compounded feeds on growth.}

The growth rates of the specimens maintained on the different compounded feeds were significantly different ( $F_{s}=7.79 ; 2$ and $\left.18 \mathrm{df}\right) \quad(P>0.05)$ corresponding to the differences in the protein contents of the feeds(Table I).LSR test showed that meals

$\mathrm{CM}_{1}$ and $\mathrm{CM}_{2}$ were similar but were different from meal $\mathrm{CM}_{3}(P<0.05)$ (Table $\left.V\right)$.

Table IV show the efficiencies of the various production 
systems and the food conversion rates(FCR) of meal $\mathrm{CM}_{3}$ as compared to those of the other two similar meals $(P>0.05)$.

\section{DISCUSSION}

\section{Influence of stocking densities on growth and survival}

The stock densities of 16 ind $\mathrm{m}^{2}$ and 27 ind. $\mathrm{m}^{2}$ produced similar results implying that both are probably suitable culture densities for the rearing of M.vollenhovenii. In stock density 27 ind. $\mathrm{m}^{2}$ specimen grew from $0.49 \mathrm{~g}$ to $2.277 \mathrm{~g}$ in 98 days and at 16 ind. $\mathrm{m}^{2}$ growth progressed from an initial weight of $1.00 \mathrm{~g}$ to $2.67 \mathrm{~g}$. in the same period. Willis and Berrigan (1977)observed that juvenile shrimp stocked in ponds at the rate 5 ind $\mathrm{m}^{2}$ and initial mean weight of $0.76 \mathrm{~g}$ produced shrimps weighing $48.688 \mathrm{~g}$ in 167 days of culture and the best growth obtained from post larvae stocked at the same density which grew from $0.09 \mathrm{~g}$. to $29.4 \mathrm{~g}$. in the same period of time. In other words, the juveniles obtained faster growth $\left(0.29 \mathrm{gd}^{-1}\right)$ than the post larvae $\left(0.17 \mathrm{gd}^{-1}\right)$. Ling (1969) reported that $M$. rosenbergii grew faster from $6 \mathrm{~g}_{\text {. }}$ to $100 \mathrm{~g}$. in 6 months at a stock density of 1.5 ind $\mathrm{m}^{2}$ while at a mean weight of $1 \mathrm{~g}$. at 10.0 ind. $\mathrm{m}^{2}$ a final production of $1.121 \mathrm{~kg} / \mathrm{ha}$ of shrimps (Macrobrachium rosenbergii) was obiained (Provenzano, 1973)

Sandifer and Smith(1997) provided the growth rate of $0.022 \mathrm{mg}^{-1} \mathrm{~d}^{-1}$ for M.rosenbergii reared in the laboratory while $0.022 \mathrm{gd}^{-1}$ and $0.007 \mathrm{gd}^{-1}$ was estimated by Malecha et al (1980)for the same species grown in the laboratory for 334 and 238 days respectively. A growth rate of $0.117 \mathrm{~g}^{-1}$ was obtained in 240 days for the same species (Smith et al. 1981). Table I and II show that M.vollenhovenii stocked at a density of 16.0 ind $\mathrm{m}^{2}$ and 27.0 ind $\mathrm{m}^{2}$ grew at the same rate as $M$. rosenbergii. while the growth of animals stocked at 54 ind $\mathrm{m}^{2}$ was different $(P>0.05)$. These minor differences in the growth rates of these two species (M.vollenhovenii and
M.rosenbergii) are probably related to the culture environment and stocking densities of the individuals in the two experiments. It is well known that higher stocking densities of individuals in any culture environment diminish the growth rates of species (Miyajima,1971; Smith et al 1981; Sarver et al,1982; and Bowser and Roosemark, 1991). The results of this study compares fairly with that provided by Miller(1971)who gave $0.26 \mathrm{~mm} . \mathrm{d}^{-1}$ as the growth rate for $M$. vollenhovenii even though the stocking sizes and densities of the species in his study were not provided.

Survival rates were high in this study (Table II) compared to those reported for $M$.rosenbergii at the densities of 215 ind. $\mathrm{m}^{2}$. and 430 ind. $\mathrm{m}^{2}(58.2 \%$ and $17.8 \%$ respectively) and $11.4 \%$ and $16.9 \%$ survival obtained at 645 and 860 ind $\mathrm{m}^{2}$ stock densities for specimens reared for 30daýs by Willis et al 1976). Wickens (1972) at even higher densities of 1222 and 1746 ind $\mathrm{m}^{2}$ measured $28.9 \%$ and $21.9 \%$ respectively for M.cosenbergii cultured for 97 days. The stocking densities in these experiment were very high compared to those investigated for this report; the low survival rates of the specimens are attributed to environmental factors(Saver et al 1982), cannibalism and high densities (Willis and Berrigan 1972). The relationship between stocking densities and survival rates is amply illustrated from the studies of Willis and Berrigan (1972) who obtained survival rates of $92 \%, 70 \%$, and $38 \%$ respectively from specimens stocked at 5,10 , and 20 ind $\mathrm{m}^{2}$ densities At the rates of $1.2,2.5$, and 3.7 ind $\mathrm{m}^{2}$ Gutherie and Tarver(1981) calculated survivals of $71 \%$, $58 \%$ and $62 \%$ respectively. However these high rates of survival were related to low stocking densities

\section{Influence of food on growth and survival}

The influence of protein levels and the nature of compounded feeds for cultured organisms is crucial in the promotion of growth in culture systems. Malecha et al (1981),Stanley and Moore(1983) found that only low

Table 2: Growth and survival of Macrobrachium vollenhovenii stocked at three densities for 98 days. Temperature $=28 \pm 2.0^{\mathrm{C}}$

\begin{tabular}{|c|c|c|c|c|c|c|c|}
\hline $\begin{array}{l}\text { Stocking } \\
\text { density } \\
\text { (ind. } m^{2} \text { ) }\end{array}$ & $\begin{array}{l}\text { Weight(g) } \\
\text { Initial Final }\end{array}$ & $\begin{array}{l}\text { Length }(\mathrm{mm}) \\
\text { Initial Final }\end{array}$ & $\begin{array}{l}\text { Growth } \\
\text { Rate } \\
\left(g^{-1}\right)\end{array}$ & $\begin{array}{l}\text { Growth } \\
\text { rate } \\
\left(\mathrm{mmd}^{-1}\right)\end{array}$ & $\begin{array}{l}\text { Specific } \\
\text { growth } \\
\text { rate }(\%)\end{array}$ & $\mathrm{PE}$ & $\begin{array}{l}\text { Sur } \\
(\%)\end{array}$ \\
\hline 16 & $1.01 \quad 2.68$ & $33.30,50.00$ & 0.02 & 0.17 & 0.52 & 0.60 & 100 \\
\hline 27 & 0.50 & 28.60 & 0.02 & 0.16 & 0.96 & 0.40 & 100 \\
\hline 54 & 0.55 & $30.90 \quad 43.90$ & 0.01 & 0.13 & 0.44 & 0.53 & 40 \\
\hline
\end{tabular}

Table 3 : Least significant range test on individuals at 3 stocking densities

Significant differences $(P>0.05)$ are represented by horizontal lines

Stocking density(ind. $\left.m^{2}\right)$

Growth rate $\left(\mathrm{gd}^{-1}\right)$

Specific growth rate $(\%)$

Production efficiency(PE)

\begin{tabular}{cc}
16 & 27 \\
0.02 & 0.02 \\
\hline 0.52 & 0.96 \\
\hline 0.60 & 0.39
\end{tabular}

0.39 
Table 4 : Macrobrachium vollenhovenii post larvae fed with different types supplemental feeds for 84 days. Temperature $=28 \pm 2.0^{\circ} \mathrm{C}$

\begin{tabular}{|c|c|c|c|c|c|c|c|c|}
\hline $\begin{array}{l}\text { Feed } \\
\text { type }\end{array}$ & $\begin{array}{l}\text { Weight }(g) \\
\text { Initial final }\end{array}$ & $\begin{array}{l}\text { Length (mm) } \\
\text { Initial final }\end{array}$ & $\begin{array}{l}\text { Growth } \\
\text { Rate }\end{array}$ & $\begin{array}{l}\text { Growth } \\
\text { rate }\end{array}$ & $\begin{array}{l}\text { Specific } \\
\text { growth }\end{array}$ & $P E$ & FCR & $\begin{array}{l}\text { Survival } \\
\text { Rates }\end{array}$ \\
\hline 6 & & & $\left(g d^{-1}\right)$ & $\left(\mathrm{mmd}^{-1}\right)$ & $(\%)$ & & & $(\%)$ \\
\hline $\mathrm{Cm}_{1}$ & $1.54 \quad 1.92$ & 51.10 & 0.02 & 0.16 & 0.73 & 0.5 & 2.43 & 50 \\
\hline $\mathrm{Cm}_{2}$ & 0.822 .46 & 41.50 & 0.02 & 0.15 & 0.06 & 0.6 & 2.48 & 50 \\
\hline $\mathrm{Cm}_{3}$ & 0.562 .62 & 34.80 & 0.03 & 0.29 & 1.43 & 0.3 & 1.33 & 50 \\
\hline
\end{tabular}

Table 5 : Least significant range test(LSR) on three supplementary diets fed to Macrobrachium vollenhovenii post larvae. Lines represent significant differences $(P>0.05)$.

\begin{tabular}{llll}
\hline Feed type & $\mathrm{CM}_{1}$ & $\mathrm{CM}_{2}$ & $\mathrm{CM}_{3}$ \\
Growth rate $\left(\mathrm{gd}^{-1}\right)$ & $\underline{0.016}$ & 0.019 & 0.025 \\
Specific growth rate(\%) & 0.73 & 0.65 & 1.43 \\
FCR & 2.24 & 2.48 & 1.33 \\
Production efficiency(PE) & 0.54 & 0.28 & 0.30 \\
\hline
\end{tabular}

protein and easily fragmented compounded feeds are suitable for the growth of $M$. rosenbergii. In this study, M.vollenhovenii fed with meals containing $55 \%$ and $30 \%$ protein exhibited similar growth as those reported by them(Tables IV and $V$ ). The main source of protein for meals $C M_{1}$ and $\mathrm{CM}_{2}$ were shrimp parts and Egaria radiata meals respectively as against meal $\mathrm{CM}_{3}$ whose main protein source was a combination of shrimp and Egaria meals in low percentages (Table I). Egaria as the only protein component for meal $\mathrm{CM}_{2}$ produced the least growth indicating that the meal alone and even shrimp meal was insufficient and inferior as independent meals. They however in combination became nutritious and efficient in the promotion of growth as evident from the result obtained from meal $\mathrm{CM}_{3}$. This results might be related to the amino acid constituents of the two protein sources composing the meal which possibly complimented each other (meal $\mathrm{CM}_{3}$ ) to promote growth only when administered in combination. The reason for the poor performance of meal $\mathrm{CM}_{1}$ is not yet understood even though the component of that feed shares similar amino acid spectrum with the cultured animals. in a similar study, Destajo and Dejarme (1980) obtained survivals of $40 \%$ and $80 \%$ from the best food administered to $M$. rosenbergii and Peneaus indicus and concluded that the best meal produced the highest survival. rates. The above stated results compared to those obtained from this study contradicts each other; differences in the stocking densities of the animals in the two studies not withstanding. Destajo and Dejarme

(1980) studied only two animals per container (size of container not provided) as compared to the 33.0 ind. $\mathrm{m}^{2}$ of this study. This implies that the stocking rates of the specimens in that study must have influenced the survival rates. It is known that the survival of individuals in culture systems is encouraged by low stocking rates.

The best FCR was calculated from those animals that fed on meal $\mathrm{CM}_{3}$ as compared to those obtained from the other two meals, implying that meal $\mathrm{CM}_{3}$ was superior to the others. FCR's calculated for other aquatic species fed at low to high stock densities ranged from 1.84 to 7.40 respectively (Smith et at 1981). Higher food consumption rates indicate poor feeding, and unacceptability of food and vice versa( Destajo and Dejarme 1980; New and Singholka, 1582).

\section{ACKNOWLEDGEMENT}

This is an extract from my PhD work concluded in 1992. I acknowledge the sponsorship of the university of Calabar, Calabar whose graduate study grant facilitated the study.

\section{REFERENCES}

Association of officials analytical chemist (A.O.A.C) 1975 Official method of Analysis $13^{\text {th }}$ edition Washington D.C

Bowser, P.R. and Roosemark P. 1981. Mortalities of cultured lobsters (Homarus)associated with moult death syndrome Aquaculture 23:1-18

D. Abramo, L.R.; Conklin, D: E Border , C.E. Baum, N

A. and Norman Boudream, N. A., 1981. Successful artificial diets for the culture of juvenile lobster J. world Mariccul, Soc. 12 (1) : $325-332$.

Davis, D. A. and Robinson ,E.H. 1986 .Estimation of the dietary lipid requirement level of the white crayfish Procambrus acutus World Aqua.Soc. 17(1-4): $37-43$

Destajo, W.,H.and Dejarme,H.E., 1982. Formation and evaluation of supplementarydiets for Penaeus indicus and Macrobracium rosenbergil juveniles. Mindano Aqua and fish, 61-71 MUSIFRD R SEARCH AND Tech. Transfer Dept.

Dockin S., Azzinaro, W. P. and Montfrans, J. V., 1974. Culture of Macrobrachium acanthurus and 
hybridisation of these shrimps Proc. of tile $5^{\text {th }}$ workshop World Marcul. Soc. Pp. 51-62.

Enin, U. I. 1994. liength- weight parameters and conditions factor of two West Africa Prawns. Revue Hydrobiol. Trop. 27(2):121-127.

Gutherie, P.W.and Tarver,J.W.1981. Malaysian Prawn culture in brackish water ponds in Louisiana $J$ World Maricul. Soc. 12 (2): 214-222.

Gordon,C.,1989, Prawn in Ghana. Iclarm Quaterly 12: $1-17$

Malecha, S. R., Sarver D., and Onizuka, D., 1980. Approaches to the study of domestication in the fresh water prawn Macrobrachium rosenbergil with speciai emphasis on the anuenue and Malaysian stock J. World Maricul. Soc 11: $50-528$.

Malecha, S. R, Buck D.H. and Onizuka, D. B.,1981. Polyculture of the fresh water prawn $M$ rosenbergii, Chinese carp and common carp in ponds enriched with swine manure. Aquaculture $25: 101-116$

Malecha,S.R.,Masuno, S, and Onizuka D.B 1984. The feasibility of measuring herebility of growth pattern variations in juvenile fresh water prawn M. rosenbergii (De man). Sea grant 00-00-00 and Hawaii agricultural expt Station Journal series No. 00-00-01

Malecha,S,R. 1986. New techniques for the assessment and optional management of growth and standing crop variation in cultured fresh water prawn M.rosenbergii. Engineering, 53: 183-197.

Mani,R. Mintordjo ,K. and Adisukreno,S., 1979.Potential protein sources of supplemental feed formulated for shrimps and prawns in Jepara. Bull .Brackish water Aqua. Dev. Center, Jepara $3(1-2): 223-230$.

Mijayima, L.S.1977. About Macrobrachium species. In: Shrimp and prawn farming in the Western hermisphere(J L Hanson and H L Godwin eds.) D. Powdeen, Hutchinson and Ross Inc. Strousberry P.A. pp 201-209

Miller,G,C. 1971, Commercial fishery and biology of the fresh water prawn Macrobrachium in the lower St. Paul river, Liberia. Spec. Sci. Rep. 626: $1-3$.

New,M.P. and Singholka S. 1982. Fresh water prawn farming. A manual for the culture of Macrobrachium rosenbergii FAO Fish Tech. Pap. 225,116p.
Powell, C.B. 1983. Fresh and brackish water shrimps of economic importance in the Niger delta. In: Proceedings of the fisheries society of Nigeria, Calabar, $\quad 25^{\text {th }}-27^{\text {th }}$ January, 1982. (E.O.Ita ed). Kainji Lake Research Institute New Bussa. Nigeria, pp $244-285$

Prah., S. K., 1982. Possibilities of pond culture of fresh water prawns in Ghana, West Africa In: Giant prawn farming M.B.New (ed.) Elselvier, Amsterdam, Oxford, New York, pp.403 - 409

Pratten, D. J., 1980. Growth in the craytish Austropotamobius pallipes (Crustecea: Astacidae) Fresh Water Biol. 10: $401-412$.

Provensano, A. J., 1973. Some result of a pilot project on fresh water prawn culture in Jamaica $\mathrm{J}$. World. Maricul, Soc. 4: $57-61$.

Sandifer, P. R. and Smith,T.I.J.,1975. Effects off population density on survival of Macrobrachium rosenbergil reared ' in circulating water management systems. J.World Maricul, Soc. $6: 43-53$.

Sarver, D., Malecha, S. R. and Onizuka, D., 1982. Possible sources of variasbility ... in stocking mortalities in post larval Macrobrachium rosenbergii pp.99 -110. In: Giant prawn farming (M.B.New ed.) Elselvier, Amsterdam.

Smith, T. I. J., Sandifer,P.R., Jenkins, W. E. and Stowes, A. D., 1981. Effect of population structure and densty at stocking on production and commercial feasibility of prawn Macrobrachium rosenbergii farming in temperate climates J.World. Maricul Soc. $13: 56-62$

Sokal , R. R. and Rohlf., F. J.,1969. Biometry: The principles and practice of statistics in biological research San Francisco, Freeman and Co. $759 p$.

Stanley, E.W. and Moore, L. D., 1983. The growth of Macrobrachium rosenbergii (De man) fed commercial feds in ponds /cages. J.World Maricul. Soc. 14: 174-184

Udo,P. J. and Taege, M., 1989. Body size and metabolic rates in Macrohrachium vollenhovenii (Herklots, 1857) (Crustecea, Decapoda. Palaemonidae) J. Aqua.Trop.4: 76 - 86 .

Udo, P. J. and Taege, M., 1991. Respiratory responses of the crustecean Macrobrachium vollenhovenii (Decapoda, Palaemonidae) to different salinities Aqua.Fish.Manag. 22: 353 $-358$ 